\title{
東京大都市圏におけるソフトウェア産業の立地 —ネスティッドロジットモデルによる分析—
}

\author{
矢部直人 (東京都立大学大学院生)
}

\begin{abstract}
1990 年代の IT 革命の後, 事業所サービス業の立地が分散する可能性が生まれた。 しかしながら, 現在ま ではさまざまな空間スケールでの集積が報告されている. 本研究は東京大都市圈において複数の空間スケー ルにわたる分析を行い，各空間スケールにおけるソフトウェア産業の立地要因を明らかにすることを目的と する. 大都市圈内のソフトウェア産業は，広域的なスケールでは 23 区および業務核都市に，局地的なスケ ールでは駅の周辺に集積している.ネスティッドロジットモデルによる分析の結果, 企業はこの二段階の空 間スケールごとに立地意思決定を行っていることが判明した。広域的な地域選択では，顧客への近接性，オ フィス賃料を評価し，局地的な地点選択では，上流工程を担当している企業が駅への近接性を主に評価する ことが明らかになった。また，1990年代には地価が下落したため，下層の企業す交通ネットワークの充実 した 23 区へ立地するようになった。

キーワード :ソフトウェア産業, 東京大都市圏, 集積, $\mathrm{K}$ 関数, カーネル密度推定法, ネスティッドロ ジットモデル
\end{abstract}

\section{I はじめに}

1. ソフトウェア産業の立地一一分散か集中か? Sassen（2001）の世界都市論は，1980 年代から 主に先進国の製造業が生産現場をグローバルに展開 したことによって，それらを統合・管理する本社部 門および事業所サービス業が世界都市と呼ばれる特 定の都市に集積することを論じた，グローバルな統 合・管理を実現する機能は自社内で供給されるので はなく，多くが専門的なサービスを提供する事業所 サービス業に外注されるようになり，世界都市では 事業所サービス業が成長したのである. 1980 年代 の東京では, 日本系多国籍企業が集積することによ って, それらを顧客とする事業所サービス業の従業 者数が大幅に増加した（町村 1994 ; 松原 1995). グローバルに拡散した生産工程を世界都市の本社に おいて統合し，管理することを可能にしたのは情報 システムの発達である（Sassen 2001）。情報シス テムを構築するソフトウェア産業は, 主な顧客であ る製造業，金融業などのグローバルな展開を可能に する，重要な事業所サービス業である1).
この時期の日本では, 富田 (1987), 小川・石川 (1989, 1990), 加藤 $(1993,1996)$, 北川 (1996) ら が，いずれあ急成長するソフトウェア産業の立地に ついて研究を行った，富田（1987）は，東京大都市 圈内の神奈川県に位置するソフトウェア産業の立地 要因を調へ，対面接触を頻繁に行うことから顧客へ の近接性を重視し，さらに従業者の確保などを考慮 して立地場所を決定していることを明らかにした。 また，特に 1980 年代に神奈川県に設立された企業 のうち，主な取引先が東京にある企業が少なからず 存在することを指摘した。小川・石川 $(1989$, 1990）は東京一極集中が問題となっていた当時の時 代背景を色濃く反映して，23 区に集中するソフト ウェア産業が，郊外の業務核都市へ分散する可能性 を検討している．都心では成長に伴う業務拡大に見 合ったオフィススペースを確保することが困難であ り，業務核都市の広いスペースと安い賃料がオフィ スを引き付ける可能性を指摘している. 特に情報シ ステム開発の中でも，さほど対面接触を必要としな い工程を担当する企業が，郊外の業務核都市へ分散 することは一定程度可能であると結論した．加藤 
(1993，1996）は東京一極集中問題に対する地方へ のソフトゥェア産業の雇用分散という点から, 東京 と仙台を例にソフトウェア産業の立地を検討した。 その結果，地方の自立的な経済を構築するすのとし て期待されたソフトウェア産業が，実際には東京か らの仕事の受注で成り立っているという，地方都市 の東京従属的な立場を明らかにしている。このよう に 1980 年代当時の日本のソフトウェア産業の立地 は，都市圏間スケールでは東京への，東京大都市圈 内スケールでは 23 区への過度な集中が問題視され ており，その対策として都市圈間では地方への，都 市圈内では業務核都市への業務分散が注目を集めて いたといえよう。

1990 年代に入ると, バブル経済の崩壊により地 価は大幅に下落する．都心部のオフィス空室率は上 昇して（松原 1995：302）, 総従業者数屯減少し た 2). 1980 年代後半のバブル経済の要因の一つは, 世界都市東京のオフィスに対する過剩な需要予測で あったことが明らかになった（吉川 1999）。1990 年代半ばを過ぎると，OSソフトウィンドウズ 95 の発売を機にパーソナルコンピュータが爆発的な普 及を始め，インターネットの商用化とともに IT 革 命と呼ばれる現象が進行した. パーソナルコンピュ ータおよびインターネットの普及により，ソフトウ エア産業はIT 産業という新たな幅広い産業の複合 体の一部分と考えられるようになる.1990 年代後 半には，IT投資が拡大し，ソフトウェア産業では 再び従業者数が増加した。

IT 革命，すなわち情報技術の利用が社会に対し て与える影響にはさまざまなことが考えられるが, 地理学で注目されてきたことの一つは，事業所サー ビス業の立地に与える影響である（石丸 1995a， b; 荒井ほか 1998). ソフトゥェア産業では, その 最終製品はインターネットを通じて送信することあ 可能であるため, 製品の輸送に関して費用はほとん どかからないと考えられる．最新の情報技術を利用
することで，企業の立地が製品の輸送費に制約され なくなり，企業が分散立地する可能性が出てきたの である。

しかしながら，最近の事業所サービス業研究でも， サービスを生産する過程で顧客および同業者との対 面接触が必要であり, 事業所サービス業は大都市に 集積する傾向にあるといわれている (Goe et al. 2000)。Zook（2000）は，IT 産業の立地を都市圈 単位で分析し，IT 産業の顧客となる既存の産業集 積との相関関係を指摘した。 Gorman（2002）も都 市圈単位で IT 産業の立地を分析し，ネットワーク の帯域幅などの IT インフラと IT 産業の立地には 相関があることを明らかにしている，以上の研究は いずれあ都市圈間単位で分析がなされており，より 詳細な空間スケールでのデータを得ることが難しい ことああって, 都市圈内の立地分析はなされていな い.

一方日本では, IT 産業の立地に関して国土交通 省（2001, 2002），経済産業省・富士通総研（2001） が，東京 23 区という比較的狭い空間スケールを対 象にして, ターミナル駅の近くに集積がみられるこ とを報告している，いまここで，事業所・企業統計 を用いて，一都三県（東京都，神奈川・千葉・埼玉 県）を対象としたやや広い空間スケールでソフトウ エア産業従業者数の動向を見ると，1996２001 年 には東京 23 区への再集中がみられる（図 1)。同じ く従業者数が増加したものの，郊外へ分散した 1980 年代当時とは対照的である.

ソフトウェア産業は, 1980 年代にはその急成長 ぶりが注目され，東京への一極集中との関係で都市 圈内, 都市圈間双方でその立地に関する研究が行わ れた. 1990 年代後半にはIT 革命によりソフトウェ ア産業は再び脚光を浴び，情報技術の発達によるオ フィス立地分散への関心が高まっているといえよう。 ところが，1990年代後半からの研究では分散では なく，さまざまな空間スケールでの集積が報告され 


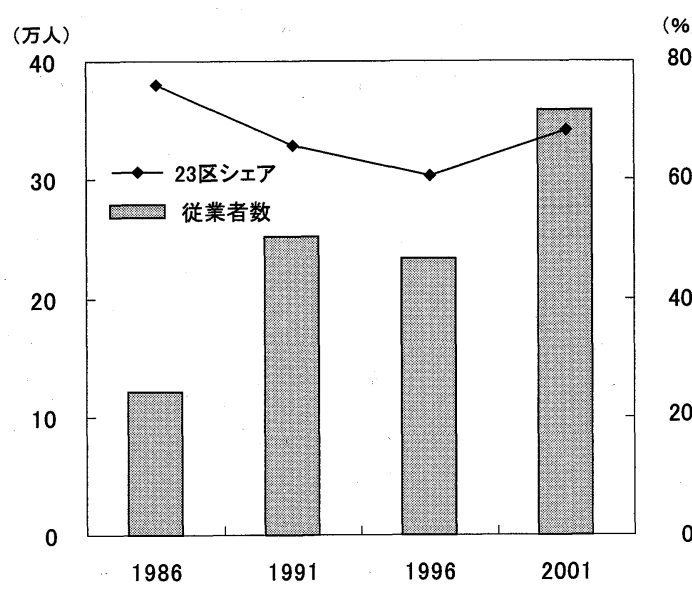

図 1 一都三県のソフトウェア従業者数と 23 区のシェア (事業所・企業統計（各年次）により作成).

Fig. 1 Number of employees in the software industry in the Tokyo metropolitan area and its share in the 23 wards of Tokyo

ている（国土交通省 2001, 2002; 経済産業省・富士 通総研 2001; Goe et al. 2000; Gorman 2002; Zook 2000,2002).さまざまな空間スケケールでの集 積を引き起こした要因は, 一般に顧客との対面接触 の必要性であるとされている. しかし，それらは各 空間スケールを個別に分析しており，複数の空間ス ケールにわたる研究はなされていない，企業は立地 場所を選定するに当たり, 最初により広域的な地域 決定, 次にその地域に属する地点決定という各段階 を経るとされている（西岡 1976：48-52).このよ うな複数の空間スケールを段階的に経る企業の立地 意思決定過程を分析することで, 各空間スケールに 対応した立地要因を明らかにすることができる。ま た, 1980 年代後半と 1990 年代後半の対照的な立地 状況（図 1 参照）を生んだ要因も定かではない，本 研究は事業所サービス業に属するソフトウェア産業 を取り上げて, 既存研究の少ない都市圈内スケール, 具体的には東京大都市圏 3) を対象地域とする. 大 都市圈内に抢いて, 複数の空間スケールにわたるソ フトゥェア企業の立地意思決定過程を検討すること で, ソフトウェア産業の立地要因の分析を試みる.

\section{2. 研究方法}

本研究で対象とするソフトウェア産業のデータは 2002 年時点での各企業の住所, 資本金, 設立年次, 取引先，業務内容などが掲載されている，シィ産業 研究所『情報処理・ソフトウェア会社録 2003 年 版』4）を用い，本社が東京大都市圈内に立地する 4,518 社を抽出した，対象企業は，資本金 5 千万円 以下の小規模な企業が約 75\% と圧倒的に多く, 設 立年次は 1980 年以降が約 $80 \%$ と大半を占めている （表 1). 業務内容（複数回答, 上位三位）は, 受託 ソフトウェア開発を行っている企業が全体の $91.1 \%$ ，自社パッケージ開発が $25.1 \%$ ，コンサル タント業務が $20.3 \%$ である.

以下，II において，システム開発工程，外注の利 用などソフトウェア産業の特徵を述べた後, 点分布 パターンを測定する $\mathrm{K}$ 関数を用いて，複数の空間 スケールで企業の空間的分布パターンを判定する. さらにカーネル密度推定法を用いて，大都市圈内に おけるソフトウェア産業の分布状況を把握する. III では企業の立地意思決定過程に注目し，ネステ イッドロジットモデルを用いて大都市圈内における 各空間スケールでの集積を形成した立地要因の分析 を行う．集積スケールに対応したネスト構造を仮定 することにより，各空間スケールにおける段階的な 意思決定について検討することが可能となる. IV では個別企業の詳細な立地意思決定過程を, アンケ 一ト調查・聞取り調查の結果から明らかにする。こ れによってネスティッドロジットモデルの計算結果 から示される，段階的な意思決定の妥当性を確認す ることができる．聞取り調查は 2003 年 5 12 月の 間に 17 社を訪問し，ほかに 3 社との間ではメール を介して行った。この聞取り調查の結果は適宜本稿 の中で用いることにする. 
表 1 東京大都市圈の対象企業の属性

Table 1 Location, amount of capital, and year of establishment of firms in the Tokyo metropolitan area

\begin{tabular}{|c|c|c|c|c|c|}
\hline \multicolumn{2}{|c|}{ 本社所在地 } & \multicolumn{2}{|l|}{ 資本金 } & \multicolumn{2}{|c|}{ 設立年次 } \\
\hline 23 区 & $\begin{array}{c}3,289 \\
(72.8)\end{array}$ & ～1 千万円 & $\begin{array}{c}1,812 \\
(40.8)\end{array}$ & $\sim 1969$ & $\begin{array}{c}229 \\
(5.1)\end{array}$ \\
\hline 業務核都市 & $\begin{array}{r}870 \\
(19.3)\end{array}$ & ～5千万円 & $\begin{array}{c}1,562 \\
(34.8)\end{array}$ & $\begin{array}{l}1970 \sim \\
1979\end{array}$ & $\begin{array}{r}765 \\
(17.1)\end{array}$ \\
\hline \multirow[t]{2}{*}{ その他 } & $\begin{array}{r}359 \\
(8.0)\end{array}$ & ～1 億円 & $\begin{array}{r}408 \\
(9.1)\end{array}$ & $\begin{array}{l}1980 \sim \\
1989\end{array}$ & $\begin{array}{c}2,242 \\
(50.0)\end{array}$ \\
\hline & & 1 億円 & $\begin{array}{r}687 \\
(15.3) \\
\end{array}$ & $\begin{array}{l}1990 \sim ~ \\
2003\end{array}$ & $\begin{array}{c}1,249 \\
(27.9) \\
\end{array}$ \\
\hline 合計 & $\begin{array}{c}4,518 \\
(100)\end{array}$ & 合計 & $\begin{array}{c}4,469 \\
(100)\end{array}$ & 合計 & $\begin{array}{l}4,485 \\
(100)\end{array}$ \\
\hline
\end{tabular}

括弧内は\%。百分率算出の際に四捨五入したため, 合計は 100\%とならない。

\section{II ソフトウェア産業の特徵および 東京大都市圏における分布状況}

1. ソフトウェア産業の特徴

1）情報システムの開発工程

日本における情報システムは，エンドユーザーの 要望に沿って開発される受注システムが大半である （富田 1987：220)。これは，標準化され大量生産さ れるパッケージソフトとは異なり，エンドユーザー の要望に沿って一つ一つカスタマイズして開発され る5)。カスタムメードのシステム開発規範とされる ウォータフォールモデルでは，上流工程であるエン ドューザーの業務分析から，システム設計，コーデ イング（設計書に沿って実際にプログラムを打ち込 む工程)，下流工程であるシステムのテストまで, 各工程を順に経て開発される。これは，情報システ ムという一つの製品を, 設計によって小さい部品 (ハードウェア，ソフトウェアの中でもインターフ エースの部分，ロジックの部分など）に細かく分割 してから各部品を製作し，最後にそれらをまとめて

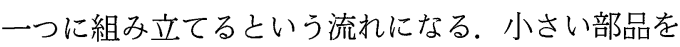
製作する工程ではさまざまな部品ごとに特化した専 門的なスキルが要求されるため, 情報システム開発 に際しては各工程間の分業が進んでいる。 上流工程
では，エンドューザーの要望を聞きながらシステム の設計をするために，ユーザーとの対面接触による 頻繁な打合せが必要である，それに対してコーディ ングは最あ人手の掛かる工程であるが，設計書通り にプログラムを打ち込む単純作業が主になるため, エンドューザーとの対面接触はさほど必要ない．

2) 外注の利用

日本の情報システムの売上は, 従業員 100 人以上 の大企業が全売上の 7 割を占める（岩田 2002：7475)。大企業がシステム開発の全工程を自社で行う ことは稀であり, 通常は工程の一部または全部を下 請へ外注する。下請に外注される工程の多くは，大 企業にはない専門的な技術を用いなければできない 部品製造，もしくは人手の掛かる単純作業である. 情報システムはバブル経済期に需要が急増したが, バブル経済の崩壊で一時情報化投資が減少するなど, 中期的にみて景気サイクルの影響を受ける.さらに， 単一年度内という短期的な期間でも，企業の決算期 に当たる年度末に需要が集中する傾向がある，その ため, 大企業は短期的 - 中期的需要変化に対応する ため，大量の人材を雇用するよりも下請に外注する ことを選択するのである．また，技術革新が激しい 業界であり，一度習得した技術むすぐに陳腐化して しまう。それを避けるために，専門性の高い技術を 
要する工程は下請に外注するのである. 技術革新は 新技術への需要を喚起するという点では需要の変化 であり, 大企業は需要の変化へ対応するために外注 を選択し，下請へとリスクを転嫁しているといえよ う.

\section{3）システム開発事例}

ここでシステム開発工程と外注利用の実態を, 実 際の事例に沿って説明したい. 新横浜のC社 (2003 年 10 月 31 日に行った聞取り調查による) で は, 2003 年 7 月上旬にダムの制御システムを受注 した．受注先は大手メーカーの横浜工場であり, エ ンドューザーからC 社に直接仕事の依頼があった わけではない. 大手メーカーと $\mathrm{C}$ 社の間には, 基 本契約と個別契約という二つの契約が交わされてい る. 基本契約はいつでも双方が取引できる状態にす るという契約であり, 個別契約は個々の開発案件に 関する契約である. 受注先の大手メーカーと C 社 は長年の取引があり, 担当者同士の信頼関係が構築 されているため, 今回の仕事に関する個別契約は電 話一本で済んだという。 大手メーカーには，こうし た基本契約・信頼関係を結んだ下請が複数存在し, つねに仕事を外注できる状態にしておくことによっ て，案件を受注してから下請を検索して新たに契約 する手間を省き, 短納期でシステムを開発できると いうメリットがある。一方，下請企業には，ある程 度安定して仕事を受注できるというメリットがある ことになる。

システム開発は, 最初の 1 力月間, 週 $2 \sim 3$ 回の ペースで受注先である横浜市内の大手メーカ一工場 を訪れて仕様の打合せ，設計を行うことから始まる。 8 月上旬に仕様が固まり, システムを構成するハー ドウェア, ソフトウェアを C 社の下請企業へ外注 する. C 社の下請は複数あり,ここにも長年の付合 いがある。 下請には納期を守ることのほかに，何ら かの専門特化した分野を作ってもらうことを打願い しているという，9月末に外注した部品が完成する
と，C社の下請である組立工場にそれらの部品の組 立てを依頼する。11 月末に組み上がったシステム を受け入れるまでの間, システムのテスト計画を作 成し，受入れ次第 $\mathrm{C}$ 社にてテストを実行する6). テストが完了した後, 運送会社に依頼し, エンドュ ーザーである富山県のダムに搬入する. 最後に現地 で $\mathrm{C}$ 社の担当者が最終テストを行い, 納品とな る7).

以上の事例では，組立てなどの単純作業，ソフト ウェアの開発などに外注が利用されており，C社が 担当するのは上流工程である業務分析，テストのみ である、C社が複数の下請を抱えており，そのC 社む大手メーカーから受注しているように, ソフト ウェア業界は少数の元請となる大手メーカーを頂点 に，その下に何層にも渡って無数の下請企業が存在 する．ソフトウェア業界がゼネコン業界と似たピラ ミッド構造になっていると言わ机るゆえである.

\section{2. 東京大都市圏における分布状況}

1）集積の測定

東京大都市圈内に扮けるソフトウェア産業の空間 的な分布パターン（後掲の図 3-a参照）を判定す るために, 点パターン分析手法の一つである $\mathrm{K}$ 関 数を用いる ${ }^{8)}$. 点パターン分析に $\mathrm{K}$ 関数を用いる ことの利点は，特定の空間スケールに左右されるこ となく集積を検出することが可能な点である，K 関数は任意の点からさまざまな距離のバッファ （円）を描いてその中に含まれる他の点を数え，そ れをすべての点に対して繰り返したものを合計する. そのため, バッファ距離を大きくするほど $\mathrm{K}$ 関数 の推定值は大きくなる．K 関数の推定式は以下の (1) 式のようになる (Gatrell et al. 1996).

$$
\hat{K}(D)=\frac{R}{n^{2}} \sum \sum_{i \neq j} \frac{I_{D}\left(d_{i j}\right)}{w_{i j}}
$$

ここで $D$ は任意のバッファ距離, $R$ は対象地域 の面積, $n$ は点の総数 (ここでは企業数), $d_{i j}$ は任 


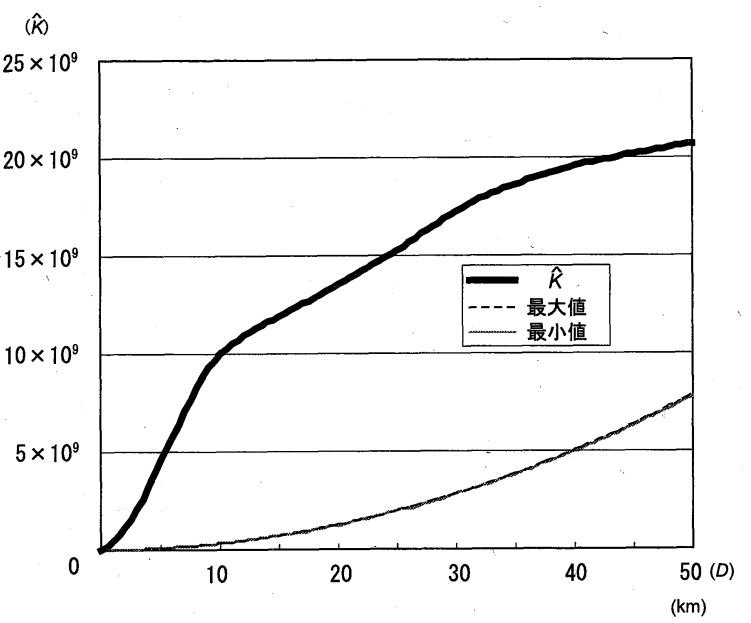

図 2 東京大都市圏におけるソフトウェア企業の空間的 分布の $\mathrm{K}$ 関数

サンプル企業数が 4,518 社と多いため, シュミレーションの最大值 と最小值の差は小さくなる.

Fig. 2 K-function for the distribution of software firms in the Tokyo metropolitan area

意の点 $i$ から $j$ までの距離, $I_{D}$ は距離 $d_{i j}$ が $D$ 以内 のときに 1 を，それ以外のときには 0 をとる指示関 数, $w_{i j}$ は境界効果の修正項 9$)$ である. $\mathrm{K}$ 関数はラ ンダムな分布状況を基準にすることで，対象となる 点の分布が集積, ランダム，均等のいずれに該当す るかを判定する．基準となるランダム分布の值が取 り得る帯域は, $n$ 個のランダムな分布に従う点を任 意の回数発生させ，その $\mathrm{K}$ 関数の最大値と最小値 を計算することで得られる．当該点分布について計 測された $\mathrm{K}$ 関数がランダムな点分布の最大值より あ大きければ集積, 最小値よりあ小さければ均等と いうように，対象となる点分布のパターンを判別す るのである。

東京大都市圏におけるソフトウェア産業の $\mathrm{K}$ 関 数を計算すると，すべての空間スケール（バッファ 距離) でランダム分布よりあ大きい值となり, 強い 集積傾向を示した（図2）．詳しく見ると，Dの值 が約 $1 \mathrm{~km}$, 約 $10 \mathrm{~km}$, 約 $35 \mathrm{~km}$ に対応する点で $\mathrm{K}$ 関数の傾きが変化することが読み取れる．Dの值が 約 $1 \mathrm{~km}$ の地点からはグラフの傾きが急になるが,
次の約 $10 \mathrm{~km}$ 地点では傾きが緩やかになり, 約 $35 \mathrm{~km}$ の地点からはさらに傾きが緩やかになる. この $\mathrm{K}$ 関数の傾きの変化は, 各空間スケールを境 に集積の度合いが増加または減少することを示して おり, 各空間スケールを境に集積を生じさせた要因 が異なるのではないかと考えられる。

2）異なる空間スケールに抢ける分布状況

$\mathrm{K}$ 関数を用いた分析により，東京大都市圈にお けるソフトゥェア産業の分布パターンは，いずれの 空間スケールでも集積傾向を示すことが判明した。

しかし, 異なる立地要因が作用しているであるう三 つの空間スケールの閾値も示唆された．実際の分布 状況を確認するために，それぞれの空間スケールに 対応する $D$ 值をカーネル密度推定法 (Gatrell et al. 1996）の検索半径に用いて，ソフトゥェア産業 の分布状況を検討する. カーネル密度推定法は任意 の点からさまざまな半径の円を描き, 円の中に入る 他の点に対して距離による重み付けをし，任意の点 における点密度を計算するあのである，検索半径が 短いほど局地的な分布傾向を, 検索半径が長いほど 平滑化された広域的な分布傾向を表すことができる.

最む広域的な傾向を表すと思われる検索半径 $35 \mathrm{~km}$ で点密度を計算すると, 都心を中心とした 同心円状に郊外へ向かって密度が低下する傾向が明 らかになった (図 3-b)。この空間スケールでの集 積は, 都心からほぼ 30〜 $40 \mathrm{~km}$ 地点にある業務核 都市以遠では, 企業がほとんど立地していないこと に対応していると思われる. つまり, 東京大都市圈 そのものに対応した集積である。

中間スケールである検索半径 $10 \mathrm{~km}$ で点密度を 計算すると，大都市圈内における広域的な分布傾向 が把握できる (図 3-c). 最む点密度の高い地域は 東京 23 区内にあり, それに次ぐのは, 川崎, 横浜 の神奈川県方面へとつながる地域である。ほかに， 千葉，柏，つくば，さいたま，八王子，立川，町田， 厚木などにも点密度が高い地域がみられる。これら 


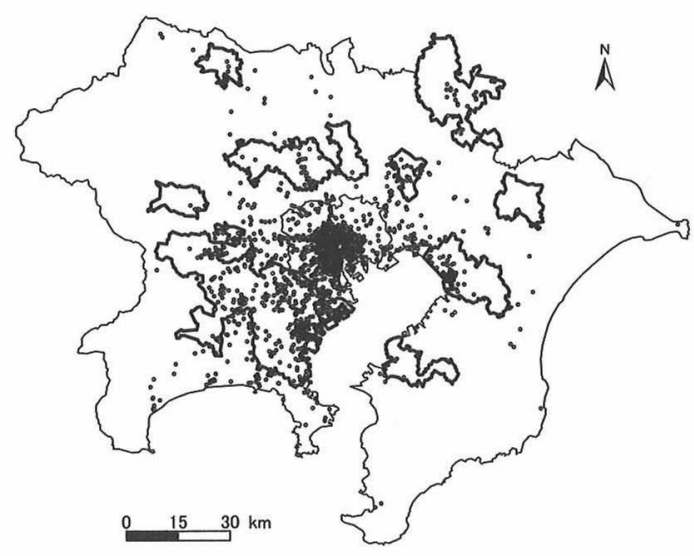

（a）ソフトウェア企業の点分布

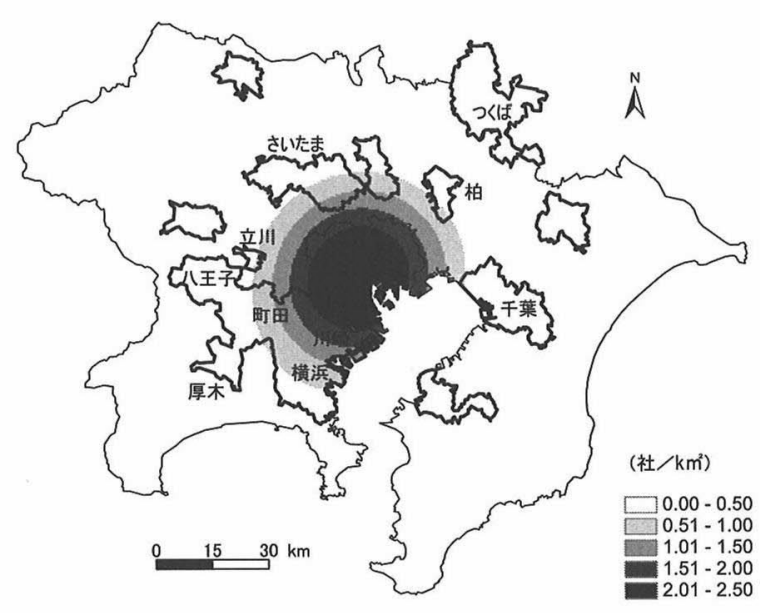

(b) カーネル密度推定法（検索半径 $35 \mathrm{~km}$ )

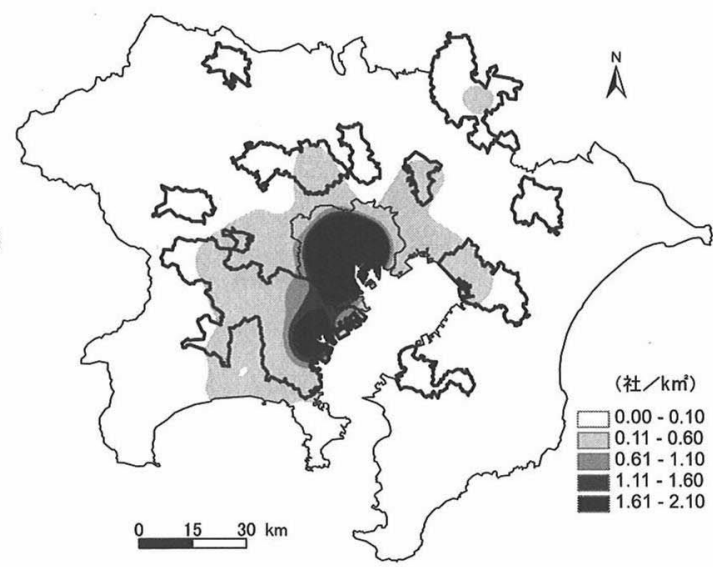

（c）カーネル密度推定法（検索半径10km）

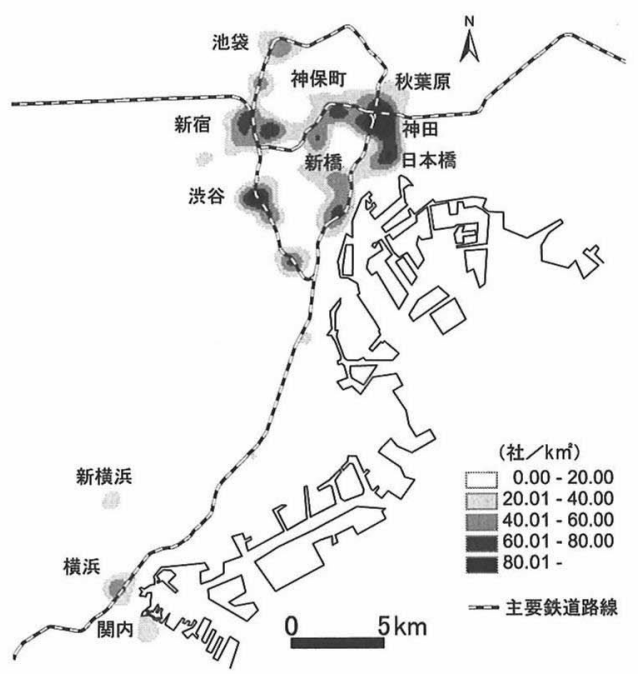

（d）カーネル密度推定法（検索半径 $1 \mathrm{~km}$ ） 図 3 東京大都市圈におけるソフトゥェア企業の分布（2002 年） 太線で囲まれた地域は第 5 次首都圈整備計画で指定された業務核都市である。

Fig. 3 Distribution pattern of software firms in the Tokyo metropolitan area, 2002

郊外の地域は国土交通省の首都圈整備計画で業務核 都市と位置づけられ, 最近の研究でも業務機能の集 積が進んでいることが報告されている. (坪本 1996；佐藤 2001；埴淵 2002；佐藤・荒井 2003). 23 区にも業務核都市にも属さないその他の地域に は，対象企業の $8 \%$ が立地しているにすぎない（表
1 参照)。この空間スケールでは, 23 区に最む高い 集積があり, 業務核都市でそれに次ぐ集積があると いえる.

検索半径 $1 \mathrm{~km}$ では，より局地的な分布傾向が明 らかになる (図 3-d)。この空間スケールでは, 鉄 道の駅周辺に集積がみられることが特徴的である. 
23 区内では, JR・地下鉄の路線が密集している神 保町〜秋葉原〜神田〜日本橋〜新橋にかけての地域 と, 新宿・渋谷・池袋など山手線の西側ターミナル 駅周辺に高い集積が目立つ。特に神田には顕著な集 積が存在するが，神田周辺の複数の企業への聞取り 調査によると，1）オフィス賃料が安いこと，2）複 数の路線 (JR・地下鉄) にアクセスできること, 3）さまざまな部品・ソフトが入手できる秋葉原に 近いことなどが評価されていた，業務核都市では横 浜駅〜関内駅・新横浜駅周辺などに集積がみられる.

以上では異なる三つの空間スケールでソフトウェ ア産業の分布パターンを確認したが，最む広域的な スケールの集積は東京大都市圈に対応しており，中 間スケールでは 23 区内に圧倒的な集積があり，そ れに横浜，千葉など業務核都市における集積が続く。 最む局地的なスケールでは駅周辺に集積がみられ， 特に複数路線が乗り入れているターミナル駅周辺に 高い集積が認められた．III では，異なる空間スケ ールに抢ける集積を形成した個別企業の立地意思決 定過程について，離散的選択モデルの一種であるネ スティッドロジットモデルを用いて分析を進める.

\section{III 意思決定過程に注目したソフトゥェア 産業の立地分析}

1. 離散的選択モデル

1）ロジットモデル

II で把握したソフトウェア産業の分布状況は，東 京大都市圈に対応した集積を除けば，広域的なスケ ールでは 23 区，業務核都市といった地域に集積が あり，より局地的なスケールでは駅周辺，特に夕ー ミナル駅周辺に集積がみられるというあのであった。 各空間スケールにおける集積を生じさせた要因を明 らかにするために, 離散的選択モデル Discrete Choice Model10)（杉浦 1992； Train 2003）の一 種である，ネスティッドロジットモデルを用いた分 析を行う.
離散的選択モデルの中で最む代表的なモデルは， 以下の（2）式で示されるロジットモデルである.

$$
P_{i}=\frac{\exp \left(V_{i}\right)}{\sum_{j} \exp \left(V_{j}\right)}
$$

ここで, $P_{i}$ は選択肢 $i$ を選ぶ確率, $V_{i}$ は選択肢 $i$ を選んだときに得られる効用である．特に選択肢が 二つの場合を二項ロジットモデル，三つ以上の場合 を多項ロジットモデルという。なお，選択肢の効用 を示す確定項 $V$ は，各選択肢に特有の選択肢特性 変数之, 選択を行う各個人に関係する個人特性変数 から成り，最尤法を用いてそれぞれのパラメー夕を 推定する.

2）ネスティッドロジットモデル

ロジットモデルの重要な特徵の一つは，IIA（Independence from Irrelevant Alternatives) 特性 を有することであり，時に現実とモデルが大きく乘 離する原因となる．IIA 特性とは，二つの選択肢が 選ばれる確率の比は二つの選択肢の関係のみで決ま り, 他の無関係な選択肢の存在あるいは追加によっ て影響を受けないというあのである.

この IIA 特性を有するロジットモデルでは選択 肢間の類似性が存在するケースに対してモデルの適 合度が低くなってしまうため，それを解決するため に考案されたのがネスティッドロジットモデルであ る11)。ネスティッドロジットモデルでは, 類似し た選択肢は一つのネストにまとめられ, 同一のネス 卜内ではIIA 特性が保たれるが，異なるネスト間 では IIA 特性は保持されない。

二層構造のネストを仮定すると，上位ネストで選 択肢 $i$ が選ばれた後に，下位ネストで選択肢 $j$ が選 ばれる同時確率は（3）式のように表される.

$$
\begin{aligned}
P(i, j) & =P(i) P(j \mid i) \\
& =\frac{\exp \left(V_{i}+\lambda U_{i}\right)}{\sum_{i} \exp \left(V_{i}+\lambda U_{i}\right)} \cdot \frac{\exp \left(V_{j \mid i}\right)}{\sum_{j} \exp \left(V_{j \mid i}\right)}
\end{aligned}
$$

すなわち, 選択肢 $i$ かつ選択肢 $j$ が選ばれる同時 確率は，上位ネストで選択肢 $i$ が選ばれる周辺確率 


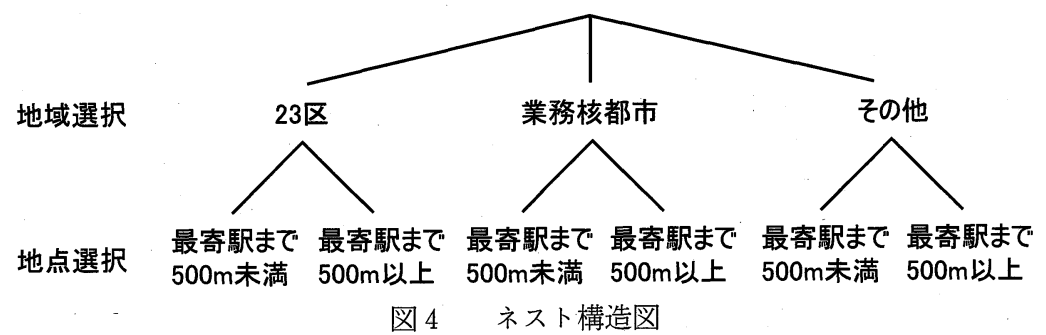

Fig. 4 Assumed nest structure

と, 選択肢 $i$ が選ばれたもとで, 下位ネストで選択 肢 $j$ が選ばれる条件付き確率の積となる ${ }^{12)}$ ）この 時, 下位ネストの合成効用 $U$ を上位ネストの確定 項に組み入れて計算することになる。下位ネストの 合成効用は（4）式のように表され，仮定したネス 卜構造が正しければ，合成効用のパラメータ $\lambda$ は 0 から 1 の間の值を取る。 パラメータ入が 1 のとき は, 仮定したネスト構造は無意味であり, 通常の多 項ロジットモデルと等しくなる.

$$
U_{i}=\ln \sum_{j} \exp \left(V_{j \mid i}\right)
$$

2. ソフトウェア産業の立地に対する適用

1）ネスト構造と説明変数

ネスティッドロジットモデルを適用するに当たり， 選択肢のネスト構造を仮定することが必要となる. 西岡（1976：48-52）は，企業は立地場所を選定す るに当たり, 最初により広域的な地域決定, 次にそ の地域に属する地点決定という各段階を経るとして いる. ソフトウェア産業の東京大都市圈内における 分布状況は，広域的な分布として 23 区，業務核都 市に集積がみられ，ょり局地的なスケールでは駅の 周辺に集積がみられるというあのであった.ここで, 広域的なスケールの集積を地域選択に，局地的なス ケールの集積を地点選択に対応するものと考え, 各 企業は各空間スケールに対応した段階的な意思決定 を行っているとする．以上のことから，上位の広域 的な地域選択には「23区内」・業務核都市」・「都 市圏内その他の地域」という三つの選択肢, 下位の
局地的な地点選択には,「最寄り駅まで $500 \mathrm{~m}$ 未 満」・最寄り駅まで $500 \mathrm{~m}$ 以上」13) という二っの 選択肢から成る二段階ネスト構造を仮定した（図 4).二段階のネスト構造を仮定したため, 本研究で 用いるモデルの式は前述（3）式と同様である，二 段階のネスティッドロジットモデルでは通常, 上位 ネストの選択肢は下位ネストの選択肢と比べて互い に独立性が強いものが用いられる14)。空間スケー ルの観点からみると，広域的な地域選択は局地的な 地点選択よりも選択肢相互の独立性が強いと考えら れるため,この点も前述のネスト構造を仮定する際 の根拠となる。

各ネストの説明変数（観察可能な確定項）は以下 の通りである，上位ネストの地域選択に関する説明 変数は，1）顧客・外注先の規模として「総従業者 数ポテンシャル」(以下,「総従業者数」と呼ぶ), 2）オフィス賃料の代替指標として「資本金規模で 重み付けした地価」(以下，「地価」と呼ぶ）を用い る ${ }^{15)}$. 以上二つの説明変数は, 各選択肢の特徵を 示す選択肢特性变数である. 総従業者数を用いるの は, ソフトゥェア産業の顧客はほぼすべての産業に わたっていることに加え，顧客にはエンドユーザー とソフトゥェア産業に属する同業者の 2 通りが考え られ，両者を区別することが困難なためである．総 従業者数は以下のようにして計算した。まず市区町 村単位で集計された総従業者数を用いて，隣接する 市区町村からの影響を取り込めるよう，距離に反比 例して減少する市場ポテンシャルを計算した 16$)$. 次に，各市区町村ごとに計算された総従業者数ポテ 
ンシャルを，23区，業務核都市といった選択肢の 区域ごとに集計して平均し，この值を説明变数とし て用いた．市場ポテンシャルを計算することにより， 上位ネストに属する選択肢間の空間的自己相関を, 説明変数で考慮することができるようになる 17).

地価は以下のようにして計算した。対象地域内に 約 12,000 地点ある公示地価デー夕から，まず内挿 により面データ（グリッドデータ）を作成する. 次 に，この面データを，23区，業務核都市といった 選択肢の区域ごとに集計して平均した。 そして，資 本金規模の大きな大企業では, 中小企業と比較して オフィス賃料の負担感が異なることが予想されるた め, 先ほど求めた地価を各企業の資本金で除した值 を説明変数とした，つまり，資本金規模の大きな企 業は地価水準には敏感に反応しないように調整した。

下位ネストの地点選択に関する説明変数は，1） システム開発工程の中で対面接触の頻度が高い上流 工程を担う企業ほど公共交通への近接性を重視する ことが予想されるため, 上流工程の業務内容を表す 指標として「コンサルタント業務」，2）同じく「要 員派遣業務」，3）企業が上流工程に位置することを 表す他の指標として「金融業・製造業などのエンド ユーザーとの直接取引」を用いる。これら三つの下 位ネストの説明变数は, 各企業の特性を示す個人特 性変数である. 下位ネストの説明变数は『情報処 理・ソフトウェア会社録』に掲載された各企業のデ 一夕から得られ, 該当業務内容, 取引先にそれぞれ 合致する場合は 1 , その他は 0 とする夕゙ミ一変数之 して分析に用いた。なお，資本金，業務内容，取引 先のうち，どれか一つでも未回答の企業は対象から 除外して分析を進めた。

以上のネスト構造と説明变数を用いて分析するに 当たり, 対象企業を設立年次により, バブル経済期 の 1980 年代とバブル経済崩壊後の 1990 年代に分け, 二つのモデルを別々に計算する 18). 1970 年代以前 設立の企業については，数が少ないことに加え，
1960 年代設立の企業などは, ソフトウェア産業と は異なる業種からの参入である可能性が高く, 立地 要因が異なると判断したため, 分析対象とはしなか った．正確な対象年代は，企業間取引情報サービス 価格指数 19）を参考にして, 価格がピークに達した 1991 年までの時期と, 1992 年以降 2000 年初頭まで の二つの時期に区分した，従業者数，地価の二つの 説明変数は, 1980 年代のモデルには 1986 年の值を, 1990 年代のモデルには 1996 年の值を用いた（表 2).

2） 1980 年代設立企業への適用結果

モデル全体の適合度は $\rho^{2}$ 値によって判定され， 回帰分析の決定係数 $R^{2}$ 值之は異なり, 通常 $0.2 \sim$ 0.4 の間にあれば良好とされる（杉浦 1992）。1980 年代の計算結果（表 $3 ） は, ~ \rho^{2}$ 值が 0.353 , 適中 率20)が $74.8 \%$ となり，ネスト構造を仮定したモ デルの当てはまりは良好といえよう21)。合成効用 のパラメータは $1 \%$ 水準で有意となり, 值む $0 \sim 1$ の間に収まっているため仮定したネスト構造は正し い，つまり，個々のソフトウェア企業はより広域的 な地域を選択した後に，局地的な地点選択を行って いるという，二段階選択の仮定は妥当なすのである と考えられる.

上位ネストの地域選択に関する説明变数では, 総 従業者数は $1 \%$ 水準で有意であり，正の係数が推定 された。このことからソフトウェア企業は顧客・外 注先の規模および近接性を評価して地域選択を行っ ていることが明らかになった，地価に対しては，有 意ではないが負の係数が推定された。これは高い地 価は一般に負の効用を生じさせると考えられること と一致している.下位ネストの地点選択ではいずれ の係数む $1 \%$ 水準で有意であり, 正の值が推定され た、このことは, コンサルタント業務, 要員派遣業 務を行っている，あるいはエンドユーザーと直接取 引がある企業は駅への近接性を重視していることを 示している.コンサルタント業務はシステム開発に おいて上流工程に位置し, 顧客との対面接触の頻度 
表 2 上位ネストの説明変数

Table 2 Explanatory variables in the upper nest

\begin{tabular}{lrrr}
\hline & 23 区 & 業務核都市 & その他 \\
\hline 1980 年代 & & & \\
地価 & $1,810,880$ & 157,355 & 88,155 \\
総従業者数 & 242,331 & 62,952 & 21,006 \\
\hline 1990 年代 & & & \\
地価 & 914,730 & 221,294 & 114,270 \\
総従業者数 & 268,093 & 69,679 & 24,647 \\
\hline
\end{tabular}

表 31980 年代設立企業の計算結果

Table 3 Results of the nested logit model for software firms established in the 1980s

\begin{tabular}{lr}
\hline & \multicolumn{1}{c}{ 係数 } \\
\hline 上位ネスト & \\
総從業者数 & $2.161^{* *}$ \\
地価 & $-0.122 \times 10^{-3}$ \\
合成効用 & $0.249^{* *}$ \\
\hline 下位ネスト & \\
コンサルタント業務 & $1.248^{* *}$ \\
要員派遣業務 & $1.044^{* *}$ \\
エンドユーザーとの直接取引 & $0.921^{* *}$ \\
\hline 適中率 & $74.8 \%$ \\
$\rho^{2}$ & 0.353 \\
サンプル数 & 1,066 \\
\hline **: $1 \%$ 水準で有意. &
\end{tabular}

が最あ高い工程である。そのため，公共交通ネット ワークへの近接性を重視するあのと推察される.

3） 1990 年代設立企業への適用結果

1990 年代のネスティッドロジットモデルの $\rho^{2}$ 值 は 0.315 ，適中率は $70.3 \%$ （表 4）となり，良好な 当てはまりを示す結果が得られた 22)。合成効用パ ラメー夕は $5 \%$ 水準で有意であり，值も 0 1 の間 にあるため, 1990 年代においても仮定したネスト 構造は正しいといえる，広域的な地域選択を行った 後に局地的な地点選択を行うという，二段階選択は 1990 年代においてあ妥当性を有しているのである. しかし，1980 年代と比較すると, モデルの適合度 を示す $\rho^{2}$ 值は 0.353 から 0.315 ，適中率は 74.8 $\%$ から $70.3 \%$ へと低下し, 合成効用のパラメータ は 0.249 から 0.415 へと上昇している. 合成効用の
表 41990 年代設立企業の計算結果

Table 4 Results of the nested logit model for software firms established in the 1990s

\begin{tabular}{lr}
\hline & \multicolumn{1}{c}{ 係数 } \\
\hline 上位ネスト & \\
総従業者数 & $2.300^{* *}$ \\
地価 & $-0.151 \times 10^{-2 * *}$ \\
合成効用 & $0.415^{*}$ \\
\hline 下位ネスト & \\
コンサルタント業務 & $1.575^{* *}$ \\
要員派遣業務 & $1.044^{* *}$ \\
エンドユーザーとの直接取引 & 0.470 \\
\hline 適中率 & $70.3 \%$ \\
$\rho^{2}$ & 0.315 \\
サンプル数 & 192 \\
\hline **: $1 \%$ 水準で有意, $*: 5 \%$ 水準で有意.
\end{tabular}

パラメータは 1 に近づくほど, 上位ネスト選択肢間 の独立性が弱まり, 多項ロジットモデルに近づくこ とを示す。これらのことから, 地域選択という上位 ネストに含まれる選択肢相互が，1980 年代と比較 して相対的に類似してきたことがうかがわれる。 総従業者数への評価は変わらず $1 \%$ 水準で有意で あり, 1990 年代にあってあ, 顧客・外注先の規模 および近接性を重視して地域選択を行っている. 地 価の係数は $1 \%$ 水準で有意となり，1980 年代と同 じく負の值が推定されていることに变わりはない. 下位ネストの地点選択であ, コンサルタント業務な ぞを担う上流工程に位置する企業は, 最寄り駅への 近接性を重視する傾向に変化がみられない。しかし， エンドューザーと直接取引をしていることは, 最寄 り駅への近接性を説明する変数として有意ではなく なっている点が 1980 年代と異なる.

以上をまとめると，両期間とも，ネスティッドロ ジットモデルを用いた計算結果は当てはまりの良さ を示しており，ソフトウェア企業の立地決定には二 段階選択が存在することを示唆している。 上位ネス 卜の地域選択には顧客および外注先の市場規模と近 接性，そして地価が評価されており，下位ネストの 地点選択では上流工程を担当する企業が駅への近接 
表 5 アンケート調査回答企業の属性

Table 5 Location, amount of capital, and year of establishment of surveyed firms

\begin{tabular}{|c|c|c|c|c|c|}
\hline \multicolumn{2}{|c|}{ 本社所在地 } & \multicolumn{2}{|c|}{ 資本金 } & \multicolumn{2}{|c|}{ 設立年次 } \\
\hline 23 区 & $\begin{array}{r}101 \\
(71.1)\end{array}$ & ～1 千万円 & $\begin{array}{r}31 \\
(23.7)\end{array}$ & $\sim 1969$ & $\begin{array}{l}10 \\
(7.5)\end{array}$ \\
\hline 業務核都市 & $\begin{array}{r}28 \\
(19.7)\end{array}$ & ～5 千万円 & $\begin{array}{r}48 \\
(36.6)\end{array}$ & $\begin{array}{l}1970 \sim \\
1979\end{array}$ & $\begin{array}{r}22 \\
(16.5)\end{array}$ \\
\hline \multirow[t]{2}{*}{ その他 } & $\begin{array}{r}13 \\
(9.2)\end{array}$ & ～1 億円 & $\begin{array}{r}18 \\
(13.7)\end{array}$ & $\begin{array}{l}1980 \sim \\
1989\end{array}$ & $\begin{array}{r}59 \\
(44.4)\end{array}$ \\
\hline & & 1 億円～ & $\begin{array}{c}34 \\
(26.0)\end{array}$ & $\begin{array}{l}1990 \sim \\
2003\end{array}$ & $\begin{array}{r}42 \\
(31.6)\end{array}$ \\
\hline 合計 & $\begin{array}{r}142 \\
(100)\end{array}$ & 合計 & $\begin{array}{r}131 \\
(100)\end{array}$ & 合計 & $\begin{array}{c}133 \\
(100)\end{array}$ \\
\hline
\end{tabular}

括弧内は\%.

(アンケート調査により作成).

性を評価している様子がうかがえた。しかし，1990 年代に入ると, 上位ネスト選択肢間の独立性が弱ま り，ネスト構造の説明力が若干低下している．また， 1990 年代にはエンドユーザーと直接取引をしてい ることは, 地点選択に関して有意ではなく, ユーザ 一と直接取引をしない下層の企業であ駅への近接性 を重視して立地していることをうかがわせる．次に IV では, 二段階選択の妥当性を経験的に確認し, 1980 年代と 1990 年代のモデル計算結果の相違につ いて検討を加えることにしたい.

\section{IV 企業の立地選択と都市構造の変化}

ここでは，個別企業へのアンケート調査・聞取り 調査に基づいて, 詳細な立地意思決定過程を明らか にし、ネスティッドロジットモデルの計算結果の妥 当性を確認する. アンケート調査は, 4, 518 社のホ ームページを検索エンジン Google で検索し，メー ルアドレスを公開していた企業 1,912 社を対象に行 った，対象企業に調査依頼のメールを送信し，送信 したメールからリンクを参照して Web 上でアンケ 一トに回答してもらった。 アンケート調查依頼のメ ールは 2003 年 10 月 20 日（月）に送信し，回答の 締切りは 11 月 14 日（金）とした。回答数は 145 社 であり，対象企業全体（表 1 参照）と比べると，回 答企業は資本金規模の大きい企業が相対的に多くな
っている (表 5)。聞取り調查は, 2003 年 5 月, 10 〜 12 月に 1 社に対し 1 時間 2 時間半ほどかけて, 145 社の中から調查に応じていただいた計 17 社に 対して行った。

\section{1. 地域選択の要因}

アンケート調查では，現在地に立地する際に考慮 した項目（「外注先への近接性」,「顧客への近接性」, 「公共交通の便」）を，1（全く重視しない）～3（ど ちらであない）～5（重視した）の 5 段階で評価し てもらった. 各項目の平均值は, 「外注先への近接 性」は 2.92 ,「顧客への近接性」は 3.85 , 「公共交 通の便」は 4.27 である.ネスティッドロジットモ デルの結果からは, 上位ネストの地域選択に関する 説明変数に総従業者数を用いたため, 顧客と外注先 への評価を区別できなかったが，実際には外注先へ の近接性はさほど考慮されていないことがわかる. これに関連して, 両国の $\mathrm{S}$ 社への聞取り調査 (2003 年 10 月 28 日実施) では, 業界の力関係の反 映から上層の企業は下層の企業の立地場所を全く意 識していないとの話む聞かれた，企業は外注先では なく, 顧客の位置を考慮して立地場所を選択すると いえよう。

顧客への近接性はどれほどの空間スケールで確保 されているのかを確認するため, 2003 年度の売上 


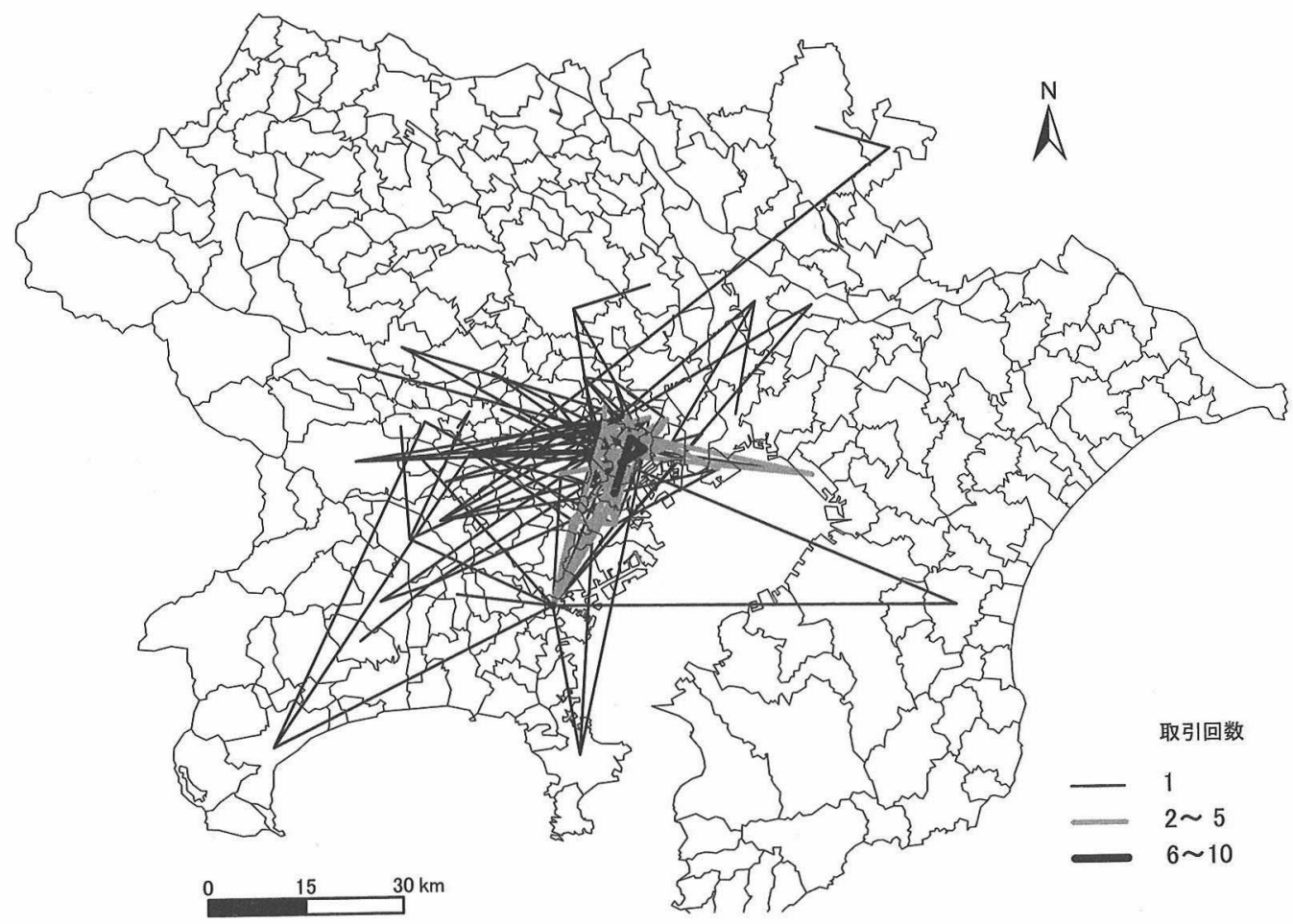

図 5 取引先の位置と取引回数

(アンケート調査により作成).

Fig. 5 Spatial pattern of transactions between software firms and their customers

表 6 本社所在地之取引先所在地の関係

Table 6 Location of software firms and their customers

\begin{tabular}{|c|c|c|c|c|c|}
\hline 本社所在地 & $\begin{array}{c}23 \text { 区 } \\
\text { 自区 他区 }\end{array}$ & $\begin{array}{l}\text { 業務核都市 } \\
\text { 自市内 他市 }\end{array}$ & その他 & 大都市圏外 & 合計 \\
\hline \multirow{2}{*}{23 区 } & $\begin{array}{r}173 \\
(75.6)\end{array}$ & \multirow{2}{*}{$\begin{array}{r}25 \\
(10.9)\end{array}$} & 11 & 20 & 229 \\
\hline & $\begin{array}{rr}31 & 142 \\
(13.6) & (62.0)\end{array}$ & & (4. 8) & & (100) \\
\hline \multirow{2}{*}{ 業務核都市 } & \multirow[b]{2}{*}{$\begin{array}{r}32 \\
(42.7)\end{array}$} & $\begin{array}{r}28 \\
(37.3)\end{array}$ & 9 & 6 & 75 \\
\hline & & $\begin{array}{rr}18 & 10 \\
(24.0) & (13.3)\end{array}$ & $(12.0)$ & (8.0) & $(100)$ \\
\hline その他 & $\begin{array}{r}14 \\
(38.9)\end{array}$ & $(22.2)^{8}$ & $\begin{array}{r}12 \\
(33.3) \\
\end{array}$ & $(5.6)^{2}$ & $\begin{array}{r}36 \\
(100) \\
\end{array}$ \\
\hline 合計 & $\begin{array}{r}219 \\
(64.4)\end{array}$ & $\begin{array}{r}61 \\
(17.9)^{6}\end{array}$ & $\begin{array}{r}32 \\
(9.4)\end{array}$ & $\begin{array}{r}28 \\
(8.2)\end{array}$ & $\begin{array}{r}340 \\
(100)\end{array}$ \\
\hline
\end{tabular}

括弧内は％．百分率算出の際に四捨五入したため，合計は $100 \%$ とならない。

(アンケート調查により作成). 
において上位 3 位を占める取引先企業の立地場所と 当該企業の現在地との位置関係を, 市区町村単位で 検討してみた（図5). 最も目立つのは，23区内, 特に山手線に隣接する区同士の間での取引である. 次いで，川崎，横浜などの業務核都市から都心方向 への取引，業務核都市間での取引となる，企業の現 在地と顧客を結んだ取引の直線距離の平均值は $12.7 \mathrm{~km}$ となり，これは II における K 関数の分析 で，傾きが変化した約 $10 \mathrm{~km}$ のスケールとほぼ対 応する．このスケールでの集積要因の一つは，顧客 への近接性であるといってよいのではないだろうか. また，当該企業の現在地と取引先の立地場所をク ロス集計すると（表 6)，23 区に立地する企業は 23 区内での取引が $75.6 \%$ と多数を占め，23 区から業 務核都市への取引は $10.9 \%$ と少ない. 23 区内の取 引であ，自区内での取引の割合は少なく，23区内 他区との取引の方が多い。このことからむ，23区 という地域に含まれる顧客への近接性を評価して, 地域選択が行われていることがうかがえる。一方, 業務核都市に立地する企業では 23 区との取引は $42.7 \%$ と，業務核都市との取引の $37.3 \%$ を若干上 回っている. 業務核都市との取引であ, 隣接してい る他の業務核都市との取引が目立つ。つまり, 業務 核都市は自立しているわけではなく，23区内との 取引によってあ支えられているのである. 2003 年 11 月 27 日に行った D 社（1989年設立）代表取締 役への聞取り調査では，本来は顧客に近い 23 区内 に立地したかったが，バブル経済期で都心のオフィ ス賃料が高かったため，また横浜方面にも23区ほ どではないが顧客がいたために立地場所として新横 浜を選んだという。 以上から, 各企業は顧客との近 接性を評価して地域を選択していることが確認され たが，業務核都市に立地する企業は 23 区内との取 引あ多く，オフィス賃料などのマイナス要因がネッ クとなって業務核都市を選択した場合もあると思わ れる.
表 7 本社所在地と他の候補地の関係 Table 7 Actual location of software firms and their planned alternative location

\begin{tabular}{|c|c|c|c|c|}
\hline 本社所在地 & $23 区$ & 業務核都市 & その他 & 合計 \\
\hline 23 区 & 49 & 1 & 1 & 51 \\
\hline 業務核都市 & 4 & 3 & 0 & 7 \\
\hline その他 & 3 & 2 & 0 & 5 \\
\hline 合計 & 56 & 6 & 1 & 63 \\
\hline
\end{tabular}

\section{2. 二段階選択の有意性}

ここで，上位ネストの選択に影響を与える要因が， 下位ネストの選択に影響を与える要因とは独立して いることを確認するために，「顧客への近接性」と 「公共交通の便」に対する評価の相関係数を計算し たところ，ケンドールの順位相関係数は 0.176 (5\% 水準で有意)，スピアマンの順位相関係数は 0.197 (5\% 水準で有意) となり，この二つの評価 はほぼ無相関であることがわかる．これにより公共 交通の便への評価は，顧客への近接性という地域選 択をする際の評価とは独立していることが明らかに なった。つまり，広域的なスケールでの集積要因と， 局地的なスケールでの集積要因は独立していること が確認されたのである。ここであ二段階選択は妥当 である可能性が高いといえよう.

立地を決定する際, 他の候補地を検討した企業は; 現在 23 区内に立地している企業で 101 社中 51 社あ り，業務核都市に立地している企業の 28 社中 7 社 と比較して，他の候補地との選択を迷った割合が多 いことがわかる．現在 23 区に立地している企業の 他の候補地は，51 社中 49 社が 23 区内（表 7）であ り，下位ネスト内の選択肢間で迷っていたことがわ かる．新宿の $\mathrm{W}$ 社への聞取り調查（2003 年 10 月 24 日実施）では，当初神保町が候補に挙がってい たが，深夜食事をする場所がないとのことで新宿を 選択したという。この業界では，納期を守るために 
表 8 資本金規模による公共交通の便に対 する評価

Table 8 Evaluation of access to public transportation by amount of capital of software firms

\begin{tabular}{c|c}
\hline 資本金 & 公共交通の便 \\
\hline$\sim 1$ 千万円 & 4.26 \\
& $(31)$ \\
$\sim 5$ 千万円 & 4.30 \\
& $(47)$ \\
$\sim 1$ 億円 & 4.06 \\
& $(18)$ \\
1 億円 $~$ & 4.30 \\
$(32)$ \\
\hline 総計 & 4.27 \\
& $(128)$ \\
\hline
\end{tabular}

括弧内は回答企業数.

(アンケート調查により作成).

夜遅くまで仕事をすることは決して稀ではなく, 深 夜に食事を取る場所があることは, 同業他社が立地 場所を決定する際にも評価項目の一つになっている とのことであった，以上のことに基づけば，23区 内に立地している企業は, 23 区外の地域に他の候 補地がある割合が極端に少ないことから，上位ネス 卜の地域選択に関しては代替性がほとんどなく, 空 間的弾力性は低いが，下位ネストの地点選択は代替 性が高く, 空間的弾力性が高いといえよう。

他方，現在業務核都市に立地している企業は，23 区内に立地する企業と比較して，他に候補地を選ん だ割合が相対的に低い，業務核都市内には他に候補 となるような駅が少ないことあ影響しているのであ ろう。現在業務核都市に立地している企業の特徵と して，上位ネストの地域選択の段階で迷っている割 合が多いことが挙げられる (表 7 参照)。この地域 間の選択を迷った企業のほぼすべては，1990年代 後半に立地選択を行った企業である. 1990 年代に は地価が大幅に下落し, 1980 年代と比較して都心 之業務核都市の地価格差は縮小している. 小川・石 川（1989）によると当時都心のオフィス賃料が坪単 価 3〜 5 万円であったが，筆者が 2003 年に行った聞 取り調査によれば, 日本橋が坪 1 万 3 千円, 新宿が
坪 1 万 2 千円であるのに対して, 新横浜では坪 1 万 3 千円と都心と変わらない賃料水準になってきてい るとのことであった：さらに業務核都市での従業員 数の増加により, 都心之業務核都市の従業員数格差 あ縮小している可能性がある（李 2002）。物件によ る違いはあるが, 都心と業務核都市で大きな賃料格 差がないところまで都心のオフィス賃料が下落した こと, さらに業務核都市の成長によって, 上位ネス 卜の地域選択の意味が若干薄まってきているといえ よう。つまり, 1980 年代には 23 区内と業務核都市 の地価格差および既存産業の集積格差が大きいため に，ネスティッドロジットモデルの二段階選択が強 く当てはまった。しかし，1990年代に入ると地価 が下落したこと，および業務核都市が成長したこと から，23区と業務核都市間の格差が縮小し，二段 階選択の意味が若干弱まり, 駅への近接性選択がよ り重要性を増したといえよう。

\section{3. 地点選択の要因}

1990 年代のモデル計算の結果では, エンドュー ザーと直接取引しない企業であ駅への近接性を重視 して立地していることが示唆された．エンドューザ 一と直接取引しない企業は，大半が資本金規模の小 さい下請企業である．そこで資本金額別に公共交通 の便に対する評価を検討すると, いずれの企業規模 であ高いことがわかった（表 8). 上流工程に位置 する企業がシステム開発工程上の対面接触の必要性 から公共交通ネットワークの結節点に位置すること はモデルから示唆されるが，1990 年代には下層に 位置する下請企業む公共交通ネットワークへの近接 性を評価することはモデル結果のみでは解釈するこ とができない，この点について, 聞取り調査の結果 から考察を加える.

仕事の受注に関して, 聞取り調査を実施したすべ ての会社に共通する興味深い点が存在する。仕事は 営業活動を行って受注するのではなく, 人脈を通し 
た紹介によって受注するということである。そそのた めほとんどの企業では, 営業活動を行う人員を置い ていない23)。この業界では, 現在の社長が独立す るときに以前の会社で自分が担当していた顧客を， そのまま自社の顧客とすることが多いようである. その最初の顧客から, 良い評価をむらい, 他の顧客 に紹介されて仕事を受注するというケースが多い. 紹介の繰返しで新規顧客を開拓していくのである. 新規の顧客を紹介されるときは, 必ず一度は顔を会 わせて，お互いの信用をある程度確認しなければな らない（2003 年 11 月 4 日実施の浅草橋 $\mathrm{R}$ 社への聞 取り調查による)。飯田橋の $\mathrm{S}$ 社（2003 年 11 月 6 日実施の聞取り調查による) では, 新しい仕事があ ると聞けば，すぐに出かけて先方と話合いを持つと いう。仕事を逃さないためには, 新規に紹介された 顧客がどこにいようとも迅速に対面接触を行う必要 がある。 そのため, 本社立地場所の交通の便が良い ことは重要なのである.

聞取り調査の結果からは, 新たな顧客を紹介され た際に迅速な対面接触を行うため, 公共交通の便を 評価していることが明らかになった，資本金規模の 小さい企業に関しては, 2000 年初頭の IT バブル崩 壊後, 事業所数が減少するなど厳しい状況が続いて いる（経済産業省 2003）。このような状況に対処し， 新たな仕事を受注するために，公共交通の便を評価 していることも考えられる. 新たな人脈を構築し, 潜在的な顧客へのアクセスを確保するために, 交通 ネットワークを需要するのである。 その際, 大都市 圏の中心に位置し, 交通インフラの充実した 23 区 内を指向する割合が高い. 地価が急騰していた 1980 年代には，オフィス賃料がネックとなり，23 区から押し出されるようにして業務核都市に立地し た企業もあった. しかし，1990年代には地価の格 差が縮小したことで, ソフトウェア産業む交通ネッ トワークの充実した 23 区内への回帰が進んでいる のである.

\section{V むす び}

本研究の結果を簡単にまとめると, 以下のように なる，東京大都市圏におけるソフトゥェア産業の分 布状況には広域的なスケール，局地的なスケールと いう二段階の集積が認められた。この二段階の集積 をネスティッドロジットモデルのネスト構造に当て はめて計算した結果, 広域的なスケールに打ける地 域選択と，より局地的なスケールにおける地点選択 という二段階の立地意思決定がなされている構造が 示唆された。 上位ネストの地域選択では顧客の市場 規模㧍よび近接性，オフィス賃料が評価される。し かし，1990 年代に入ると地価が下落し，かつ業務 核都市の成長を反映して 23 区と業務核都市の格差 が縮小してきたため, 二段階選択の有意性が若干減 少した。 下位ネストの地点選択では上流工程に位置 する企業が駅への近接性を重視することがモデルか ら判明したが, 1990 年代に入ると下層の下請企業 あ駅への近接性を重視していることが明らかになっ た、これには, 既存の顧客のみでなく, 新たな仕事 を受注しなければならなくなった小企業の姿勢が表 れているといえよう。仕事の受注には対面接触が必 須であり，頻繁な対面接触には交通ネットワークへ の近接性が重要である。二段階選択の有意性が減少 したことと合わせると，交通ネットワークへの近接 性がソフトウェア企業の重要な立地要因になってき ていると考えられる. バブル経済の崩壊でオフィス 貨料が下落したことああり, 交通インフラの充実し た 23 区を指向するソフトウェア関連企業の割合は 増加している.

1980 年代の世界都市東京は, “Japan as No. 1” と言われた日本系多国籍企業のグローバル展開を支 える本拠地として存在していた，ところが，その成 長への期待は過剩なあのであり, 結局はバブルとい う結果に終わった. 1989 年当時, アメリカ, イギ リス，日本の海外直接投資額はほぼ同じ水準にあっ 
た．それが 1990 年代に入ると，アメリカ，イギリ スの海外直接投資額が 1989 年と 1999 年の比較でそ れぞれ約 4 倍, 約 5 倍増加しているのに対し, 日本 の海外直接投資額は約半分の水準に落ち込んでいる (町村 2002：103)。国内の金融業に関してあ不良債 権処理の遅れからくる金融システムへの不安が拡大 し，金融危機が発生したことは記憶に新しい，クリ ントン政権によって製造業から金融・情報産業へと 資源を集中させ，ニューエコノミーと呼ばれた好景 気を享受したアメリカとは対照的である.こうした 経済動向を踏まえると, 1990 年代後半の日本のソ フトウェア産業の成長は, グローバルに展開する日 本系多国籍企業の需要というよりは, IT 革命・技 術革新による国内の新たな需要が寄与したものであ る可能性が高い. 今後, 国内の市場が飽和に近づい ても，対面接触を行う際に使われる日本語がカス夕 ムソフトウェア輸出の障壁となり, 海外に市場を求 めることは難しい，輸出の障壁であると同時に輸入 の障壁でああった日本語に保護されていた市場は, 近年の中国・インドの成長, 彼らの日本語の習熟に よっておびやかされつつあるようにあ見える. 限ら れた日本語の市場へアクセスするためには，大都市 圏の中心に位置し，交通ネットワークの充実した都 心が最も有利な立地場所となるのである.

アンケート調查・聞取り調查に御協力下さった企業の 方々にお礼申し上げます。また，さまざまな助言をいた だいた杉浦芳夫先生を始め, 東京都立大学大学院理学研 究科地理科学専攻都市 - 人文地理学研究室の皆様, 英文 要旨を校閲していただいたファル・ウスマン氏にもここ に記して感謝いたします。本稿は 2003 年度東京都立大 学大学院理学研究科に提出した修士論文を加筆・修正し たものであり, 内容の一部は 2004 年 5 月の 2004 年度東 北地理学会春季学術大会において発表した.

$$
\begin{array}{ll}
\text { (投稿 } & 2004 \text { 年 } 8 \text { 月 } 24 \text { 日) } \\
\text { (受理 } 2005 \text { 年 } 1 \text { 月 } 8 \text { 日) }
\end{array}
$$

\section{注}

1）ソフトウェア産業の年間売上高の約 $40 \%$ は製造業,
金融・保険業向けで占められている（岩田 2002：2829).

2）事業所・企業統計によると，東京都心三区の従業者数 は 5 年前と比較して 1996 年では $0.6 \% ， 2001$ 年では $3.9 \%$ の減少となっている。

3）東京都, 神奈川県, 千葉県, 埼玉県および東京駅から $50 \mathrm{~km}$ 圏内に含まれる茨城県の市町村を含む. 本研究 ではこれを東京大都市圈と定義する.

4）対象業種は情報システム開発，プログラム作成，パッ ケージソフト開発，ソフトウエア作成コンサルタント， ソフトウエア要員派遣, 受託計算サービス, コンピュー 夕および関連商品販売などであり，これらのいずれかを 専業または兼業に受託する企業が収録されている.

5） マイクロソフト社のエクセル・ワードなどがパッケー ジソフトウェアの代表例である. アメリカではパッケー ジソフトウェアの開発比率が日本に比べて多いため, 日 本と比べてプログラマーの人数が多く, SE（システム エンジニア）の人数は少ない.

6）聞取り調查を行った 10 月末の時点では，今後の予定 ということで話をうかがった，通常，開発案件ごとに工 程表の形で計画が作成されており, 今後の予定が把握で きる.

7）納期は半年となっている，最近は半年程度の納期が多 いが，以前は 2 年にわたる納期もあったという.

8）企業の住所（〜丁目〜番地〜号まで）を, アルプス社 の地図ソフト「プロアトラス W」を用いて経緯度座標 に変換することにより, 企業の点デー夕を作成した.

9）境界効果は, 対象地域の境界付近にある点を割り引い て計算することによって修正される. $\mathrm{K}$ 関数の計算に 用いたソフトウェアでは, 東京大都市圏の実際の境界線 を用いることが不可能なため, 全企業をその中に含む最 小の長方形を境界線として計算した.

10）連続量を扱う回㷌分析とは異なり, 質的に異なる離 散值を扱うことが一つの特徴である. 1970 年代から研 究が進められ, 初期からの研究者である McFadden は 2000 年にノーベル経済学賞を受賞した.

11）ネスティッドロジットモデルの他に選択肢間の類似 性を考慮した離散的選択モデルとして Mixed Logit Model などがある.

12）確率の乗法定理 $P(A \cap B)=P(A) \cdot P(B \mid A)$ では, 事象 $A$ 之事象 $B$ が同時に起こる同時確率 $P(A \cap B)$ は, 事象 $A$ が起こる周辺確率 $P(A)$ と事象 $\mathrm{A}$ が起こった条件のも とで事象 $B$ が起こる条件付確率 $P(B \mid A)$ の積として求め られる.

13）飯田橋の $\mathrm{S}$ 社（2003 年 11 月 6 日実施の聞取り調査 による）は, 最寄り駅から最大であ徒歩 8 分以内の場所 にオフィスを探したとのことであった. 本研究で区切り とした $500 \mathrm{~m}$ は, 分速 $80 \mathrm{~m}$ で歩くと約 6 分かかる距離 
である.しかしここで用いた $500 \mathrm{~m}$ という距離は駅 から当該企業までの直線距離であり, 実際の道路距離に よる所要時間は 6 分よりあ若干長くなる.

14）二段階の異なる空間スケールでネスト構造を仮定す ることは，日本の人口移動先選択を扱った石川 (1994), ブラジルの工場立地選択を扱った Hansen（1987）など でも行われている。、いずれの研究す上位ネストには広域 的な選択肢を，下位ネストには，それよりむ狭い空間ス ケールの選択肢を仮定している.

15）オフィス賃料を地域ごとに得るのは困難であるため, 公示地価を用いた. また, 従業者確保の指標として, 20〜 39 歳人口を説明变数として計算したが，有意な結果は 得られなかった。

16）市区町村 $i$ の市場ポテンシャル $M_{i}$ の計算式は,

$$
M_{i}=\sum_{j} \frac{P_{j}}{D_{i j}^{\beta}}
$$

となる．ただし， $P_{j}$ は市区町村 $j$ の従業者数， $D_{i j}$ は市区 町村中心 $i, j$ 間の距離, $\beta$ は距離抵抗パラメータである (ここでは $\beta=1$ とした).

17）誤差項は選択肢間で独立なので，確定項で選択肢間 の相関を考慮する必要がある.

18）企業の設立年以後の移動は『情報処理・ソフトウェ ア会社録』から把握することは不可能であり，ここでは 考慮していないことを注意されたい.

19）「日本銀行 統計・デー夕」http://www2.boj.or.jp/ dlong/price/price2.htm（2004 年 1 月 4 日検索).

20）一番高い選択確率の選択肢と実際の企業の選択を比 較し，実際の選択と同じであった場合の比率である.

21）ネスティッドロジットモデルの有効性を確認するた め，ネスト構造を仮定しない多項ロジットモデルも比較 のために計算した．多項ロジットモデルの $\rho^{2}$ 值は 0.290 ，適中率は $65.3 \%$ となり，いずれの值む多項ロジ ットモデルよりネスティッドロジットモデルの方が適合 度が高いことを示している。

22）比較のために計算した多項ロジットモデルの結果は, $\rho^{2}$ が 0.271 ，適中率が $63.0 \%$ となり，1990 年代におい ても, 多項ロジットモデルよりネスティッドロジットモ デルの方が適合度が良好である。

23）パッケージソフトウェアの販売には営業人員が必要 となるため，パッケージソフトウェア開発を行っている 新宿の A 社では営業員が配置されていた（2003年 10 月 28 日実施の聞取り調査による).

\section{文 献}

荒井良雄 - 箬本健二 - 中村広幸 - 佐藤英人 1998. 企業活 動における情報技術利用の研究動向. 人文地理 50:550 -571 .
石川義孝 1994. 二段階目的地選択の検討．石川義孝『人 口移動の計量地理学』194-215. 古今書院.

石丸哲史 1995 a. 地理学における事業所サービス業研究 の視点——英米の研究動向から. 人文地理 47: 379-402. 石丸哲史 $1995 b$. 事業所サービス業に関する実証的研究 の動向と課題. 経済地理学年報 41: 243-264.

岩田昭男 2002. 『図解 ソフトゥェア業界ハンドブック』 東洋経済新報社。

小川剛志・石川 允 1989. 東京圈における情報処理産業 の立地動向とその集結要因について，日本都市計画学会 学術論文集 $24: 67-72$.

小川剛志・石川 允 1990 . 東京における情報処理産業の 分化形態と空間的配置構造に関する研究. 日本都市計画 学会学術論文集 25：427-432.

加藤幸治 1993. 仙台市におけるソフトウェア産業の展開. 経済地理学年報 39：318-339.

加藤幸治 1996. 情報サービスの地域的循環とその東京一 極集中一一東北地域を事例として. 地理学評論 $69 \mathrm{~A}$ ： 102-105.

北川博史 1996. わが国主要コンピュータメーカーにおけ るソフトウェアハウスの展開. 人文地理 48: 499-516.

経済産業省 2003、『特定サービス産業実態調査報告書 平 成 14 年 情報サービス業編』経済産業統計協会.

経済産業省・富士通総研 2001.『東京のネット企業実態調 查』経済産業省.

国土交通省 2001.『ソフト系 IT 産業の㥶態調査報告書』 国土交通省.

国土交通省 2002.『平成 14 年度版 ソフト系 IT 産業の実 態調查報告書』国土交通省.

佐藤英人 2001. 東京大都市圏におけるオフィス立地の郊 外化メカニズム—大宮ソニックシティを事例として. 人文地理 53: 353-368.

佐藤英人 - 荒井良雄 2003. 情報部門の機能強化に伴うオ フィス立地の郊外化. 人文地理 55: 367-382.

シィ産業研究所 2002.『情報処理・ソフトウェア会社録 2003 年版』シィ産業研究所.

杉浦芳夫 1992. 空間的行動のネスティッドロジット・モ デリングに関する覚え書き. 理論地理学ノート 8：123.

坪本裕之 1996. 東京大都市圈におけるオフィス供給と業 務地域の成長. 人文地理 48: 341-363.

富田和暁 1987. 神奈川県におけるソフトウェア産業の立 地展開. 経済地理学年報 33：216-227.

西岡久雄 1976. 『経済地理分析』大明堂.

埴淵知哉 2002. 企業の空間組織からみた日本の都市シス テム. 人文地理 54：389-404.

町村敬志 1994.『「世界都市」東京の構造転換』東京大学 出版会. 
町村敬志 2002. 世界都市からグローバルシティへ. 梶田 孝道・宮島 喬編『国際社会 1 国際化する日本社会』 97-128. 東京大学出版会.

松原 宏 1995. 資本の国際移動と世界都市東京. 経済地 理学年報 41：291-307.

吉川 洋 1999.『転換期の日本経済』岩波書店.

李 政勲 2002. 東京大都市圏における都心オフィス機能 の郊外移転の要因. 人文地理 54：452-470.

Gatrell, A. C., Bailey, T. C., Deggle, P. J., and Rowlingson, B. S. 1996. Spatial point pattern analysis and its application in geographical epidemiology. Transactions of the Institute of British Geographers $21: 256$ 274.

Goe, W. R., Lentnek, B., MacPherson, A., and Phillips, D. 2000. The role of contact requirements in producer services location. Environment and Planning $A$ 32: 131-145.
Gorman, S. P. 2002. Where are the web factories: The urban bias of e-business location. Tijdschrift voor Economische en Sociale Geografie 93: 522-536.

Hansen, E. R. 1987. Industrial location choice in Sao Paulo, Brazil A nested logit model. Regional Science and Urban Economics 17: 89-108.

Sassen, S. 2001. The global city. 2nd Edition. Princeton, NJ : Princeton University Press.

Train, K. E. 2003. Discrete choice methods with simulation. Cambridge, UK: Cambridge University Press.

Zook, M. 2000. The web of production: The economic geography of commercial internet content production in the United States. Environment and Planning A 32: 411-426.

Zook, M. 2002. Grounded capital : Venture financing and the geography of the internet industry, 19942000. Journal of Economic Geography 2: 151-177. 


\title{
Location Analysis of Software Industries in the Tokyo Metropolitan Area: A Nested Logit Model
}

\author{
YABE Naoto (Graduate student, Tokyo Metropolitan University)
}

In the 1980s, the number of producer service industries increased rapidly in Tokyo, which was once called a "global city". They experienced such rapid growth that agglomeration diseconomy became an issue. To tackle this problem, software industries, which are part of the producer service industry, were either dispersed to Tokyo metropolitan suburban centers or to other metropolitan areas on an intermetropolitan scale. In the 1990s, the information technology impacts on the location pattern of producer service industries led to much debate. Several studies reported not dispersion but a concentration of such businesses on several different scales. There is, however, a lack of location analysis that integrates different scales in their approaches. This paper aims to clarify the forces driving software industries' location choices in intrametropolitan areas by integrating two different scales.

The distribution pattern of software industries shows a concentration of firms in both city centers and suburban centers on a regional scale. However, high concentrations of software firms have also been noted around some train stations on a local scale. A nested logit model was performed to analyze the hierarchical location choices. The results revealed that firms focus on market size and office rental cost on a regional scale, but their choices are based on train station accessibility on a local scale. These results indicated that firms appreciated different factors in different spatial scales.

In the $1990 \mathrm{~s}$, due to land price decreases and employment loss in inner Tokyo, the situation changed significantly. Hence, software firms could locate more easily in inner Tokyo than in the 1980s. They frequently make face-to-face contact with their customers in the inner city by taking advantage of efficient public transportation networks.

Since the collapse of the bubble economy, Japanese transnational corporations have decreased their foreign direct investment. The demand for global networking information systems, which are provided by software industries, became limited in Tokyo. They now face competition from low-cost software industries in China and India. To survive in the fierce competitive environment, choosing the inner city of Tokyo in terms of office location is one way to revitalize their shrinking market.

Key words : software industry, Tokyo metropolitan area, agglomeration, K-function, kernel density estimation, nested logit model 